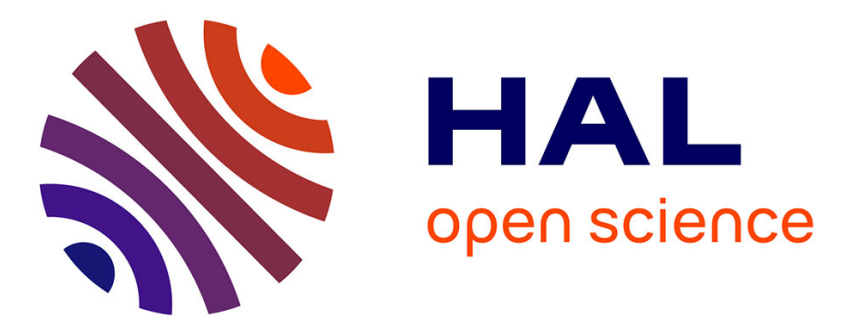

\title{
MICROSTRUCTURE VS MOLECULAR STRUCTURE OF SILICA GLASS FROM SILICON ALKOXIDE
}

G. Garvey, L. Klein

\section{- To cite this version:}

G. Garvey, L. Klein. MICROSTRUCTURE VS MOLECULAR STRUCTURE OF SILICA GLASS FROM SILICON ALKOXIDE. Journal de Physique Colloques, 1982, 43 (C9), pp.C9-271-C9-274. 10.1051/jphyscol:1982950 . jpa-00222479

\section{HAL Id: jpa-00222479 https://hal.science/jpa-00222479}

Submitted on 1 Jan 1982

HAL is a multi-disciplinary open access archive for the deposit and dissemination of scientific research documents, whether they are published or not. The documents may come from teaching and research institutions in France or abroad, or from public or private research centers.
L'archive ouverte pluridisciplinaire HAL, est destinée au dépôt et à la diffusion de documents scientifiques de niveau recherche, publiés ou non, émanant des établissements d'enseignement et de recherche français ou étrangers, des laboratoires publics ou privés. 
JOURNAL DE PHYSIQUE

Colzoque C9, supplément au n², Tome 43, décembre 1982

page $\mathrm{C} 9-271$

\title{
MICROSTRUCTURE VS MOLECULAR STRUCTURE OF SILICA GLASS FROM SILICON ALKOXIDE
}

\author{
G. J. Garvey and L. C. Klein \\ Rutgers, The State University of New Jersey, Ceranics Department, P.0. Box 909, \\ Piscatcoway, NJ 08854, U.S.A.
}

\begin{abstract}
Résumé.- En partant des mesures physiques simples, une image est proposée de la microstructure d'un gel séchẻ monolithique de silice préparé à partir de 1'orthosilicate d'éthyle. On a mesuré la masse spécifique et la dimension des échanti1lons et suivi les pertes de poids au cours du séchage du gel, jusqu'à l'obtention d'un verre totalement compact. Les gaz êmis pendant le chauffage ont été analysés. Les résultats sont interprêtés et comparés aux études publiées sur la structure moléculaire des gels secs.
\end{abstract}

Abstract. - Using simple physical measurements, a picture was constructed of the microstructure of a dried monolithic silica gel prepared from tetraethyl orthosilicate (TEOS). The density and dimensions were measured. Weight loss was monitored during heating of the gel to a fully dense glass, and gases escaping during heating were analyzed. The results were interpreted for the dried gel and compared to published studies of its molecular structure.

1. Introduction. - When water and tetraethyl orthosilicate (TEOS) are dissolved in ethanol, the solution undergoes hydrolyzation and condensation polymerization to create complex silanols. Alkoxy groups and hydroxyl groups react to build larger units with bridging oxygens. The solution which is initially fluid becomes a viscous liquid which sets to a gel filling its container. This sol-gel process produces an optically transparent, amorphous shape when the appropriate combination of acid, water and temperature is used (1). The microporous dried gel can be converted to a dense inorganic glass at temperatures well below the melting temperature, which in this case for pure silica is about $1723^{\circ} \mathrm{C}(2,3,4)$.

On closer inspection, the sol-gel process is not only an alternative method to melting, but also a method for changing the chemistry and structure of the glass. Changes in chemistry may be brought about by controlling the extent of hydrolyzation (5). In this way, the organic content or water content can be changed (6). Changes in structure are brought about by the interaction of hydrolyzation and polymerization.

There are really two levels of structural changes in the gels during drying and firing to an inorganic, dense glass. First, there are the changes in microstructure in terms of pore volume and pore morphology. Second, there are the changes in molecular structure in terms of degree of cross-linking and number of bridging oxygens. The purpose of this investigation is to characterize dried and fired gels using simple physical measurements to get an idea of the effect of water on microstructure. This information can then be compared to investigations of molecular structure, where the detection of such changes is somewhat less direct.

Several suggestions that changes in molecular structure result from processing conditions have been made on the basis of various experimental techniques. For example, infrared $(7,8)$ and visible (9) spectroscopy data have been interpreted to indicate subtle differences in molecular structure between gels and melted glasses. Nucleation and crystallization behavior have been compared for gels and melted glasses, and even when the difference in water content is taken into 
consideration, there appears to be distinctly different behavior (10). More recently, scanning calorimetry data have been interpreted to mean that the behavior for a gel in the glass transition region is typical of behavior for a rapidly quenched glass (11).

In order to relate gel microstructure to its molecular structure, gels were prepared with four water levels representing enough water to hydrolyze to eight times the water needed to hydrolyze a mole of TEOS. Gel density, weight loss and shrinkage were measured after drying; then total weight loss and gas evolution during firing were measured (12). In line with results from BET measurements (5) and small angle $x$-ray scattering (13) a simple model for the gel microstructure has been proposed and compared to gel molecular structures proposed on the basis of infrared spectroscopy $(2,7,8)$.

2. Experimental procedure. - All samples studied here were prepared by using a modification of a vacuum distillation process (14). Mixtures of TEOS, ethanol and 2, 4, 8 or 16 moles of $\mathrm{H}_{2} \mathrm{O}$ per mole of TEOS were refluxed with acid for three hours in a three-necked flask. After cooling the reaction flask to about $5^{\circ} \mathrm{C}$, the reflux condenser was exchanged for a rush-over condenser leading to a fraction cutter and then to a cold trap in a dry ice-acetone bath. The condenser was connected to a mechanical pump and a vacuum of about $10 \mathrm{~mm} \mathrm{Hg}$ was drawn. As primarily ethanol was removed from the flask, the density of the solution increased. Samples were extracted periodically and cast into $55 \mathrm{~mm}$ plastic Petrie dishes where the solution gelled. The dishes were placed in the laboratory at room temperature and allowed to dry slowly over a period of one month.

At the end of this period, the samples were uncovered and characterized for number of fragments, radial shrinkage, weight loss on drying and dry density. For each water level there were samples which dried in one piece. The monolithic samples were characterized further for total weight loss during firing from 120 to $800^{\circ} \mathrm{C}$, and a measure of percent weight loss for oxidation of residual organics in air at $410^{\circ} \mathrm{C}$ was obtained with simultaneous thermal analysis (DTA) and thermal gravimetry (TGA) in a Mettler thermal analyzer. The measure of organic content was compared to the amount of gas evolved during firing which was condensed in a cold trap and titrated for water level with Kar1 Fisher reagent.

In addition, four samples were selected for firing to $1000^{\circ} \mathrm{C}$, thereby duplicating the density of fused silica. These samples are listed in the Table. They were heated in vacuum at $4 \% / \mathrm{min}$ to $270^{\circ} \mathrm{C}$, held in air for $60 \mathrm{~min}$, heated in air at $4 \% / \mathrm{min}$ to $400^{\circ} \mathrm{C}$ and held for $60 \mathrm{~min}$, and finally heated in vacuum at $40 / \mathrm{min}$ to $1000^{\circ} \mathrm{C}$ and held for 2 hours. The total cycle took 8 hours.

3. Experimental results. - Monolithic samples were formed when 1000 m 1 of reactants were hydrolyzed with $10 \mathrm{ml}$ iN $\mathrm{HNO}_{3}$ for 3 hours under refluxing, followed by increasing the solution density to between 1.0 and $1.1 \mathrm{~g} / \mathrm{cm}^{3}$ by vacuum distillation, casting the solution into plastic molds and drying at room temperature. After one month of drying, the densities of the gels ranged from $1.5 \mathrm{~g} / \mathrm{cm}^{3}$ to $1.8 \mathrm{~g} / \mathrm{cm}^{3}$. The dry density is plotted in Fig. 1 for the four water levels. The gel made with eight times the water needed for hydrolysis has the lowest density. In Fig. 2 the percent weight loss on drying is plotted on the left-hand side and the percent radial shrinkage is plotted on the right-hand side for the four water levels. The gel with 16 moles $\mathrm{H}_{2} \mathrm{O}$ loses about twice as much weight and shrinks twice the distance as does the gel with 2 moles $\mathrm{H}_{2} \mathrm{O}$.

When the dried samples were heated in air in the thermal analyzer to $800^{\circ} \mathrm{C}$, there was an exothermic peak at $410^{\circ} \mathrm{C}$. In Fig. 3 the weight loss associated with this peak is plotted on the right-hand side along with the relative peak height on the left-hand side. The peak height is highest for the gel with 2 moles $\mathrm{H}_{2} \mathrm{O}$. Finally, in Fig. 4 the total weight 10 ss between 120 and $800^{\circ} \mathrm{C}$ is plotted for the four water levels. For this range, the gel with 2 moles $\mathrm{H}_{2} \mathrm{O}$ loses slightly more weight than the gels with higher water levels. The same trend is found for the gas condensed in a cold trap which was titrated for water level. The gel with 
Table: Firing behavior of samples that dry in 1 piece

\begin{tabular}{|c|c|c|c|c|c|}
\hline Sample & $\begin{array}{l}\text { Ratio } \\
\text { moles } \mathrm{H}_{2} \mathrm{O} \\
\text { moles TEOS }\end{array}$ & $\begin{array}{c}\text { Electrolyte } \\
\text { addition } \\
\text { in g } \\
\end{array}$ & $\begin{array}{l}\text { Casting } \\
\text { density } \\
\text { in } \mathrm{g} / \mathrm{cm}^{3} \\
\end{array}$ & $\begin{array}{c}\begin{array}{c}\text { Drying } \\
\text { temperature } \\
{ }^{\circ} \mathrm{C} \\
\end{array} \\
\end{array}$ & Comment \\
\hline A & 16 & $21(27 \% \mathrm{HCI})$ & 1.02 & 22 & Cracked \\
\hline B & 2 & $9\left(70 \% \mathrm{HNO}_{3}\right)$ & 1.05 & 22 & Discolors \\
\hline $\mathrm{C}$ & 16 & $14.5\left(70 \% \mathrm{HNO}_{3}\right)$ & 1.04 & 22 & Cracked \\
\hline D & 16 & $14.5\left(70 \% \mathrm{HNO}_{3}\right)$ & 1.05 & 70 & Monolithic \\
\hline
\end{tabular}

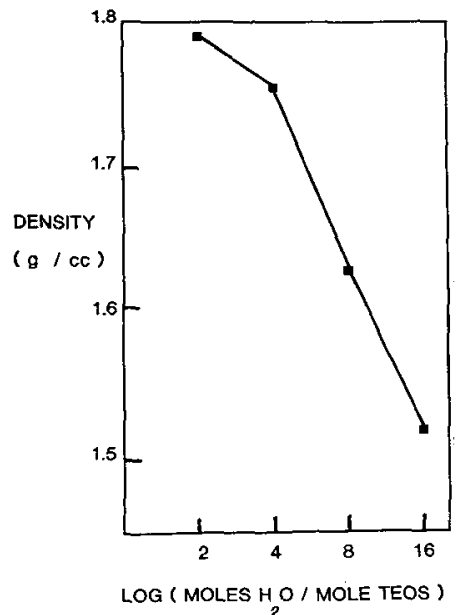

Fig. 1 - Density of slowly dried gels for 4 water levels.

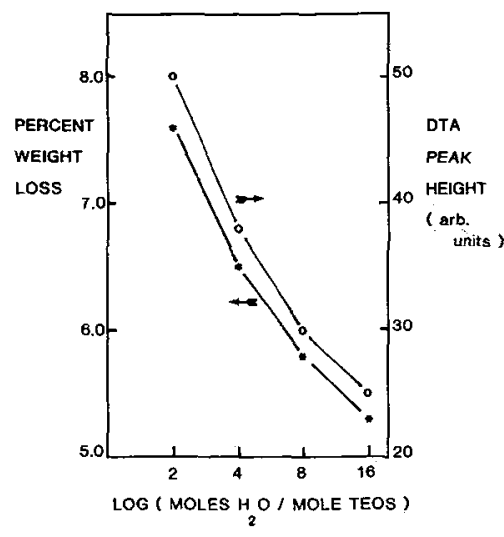

Fi.g. 3 - Weight loss and relative peak height from DTA for oxidation of organics in air at about $410^{\circ} \mathrm{C}$ for 4 water levels.

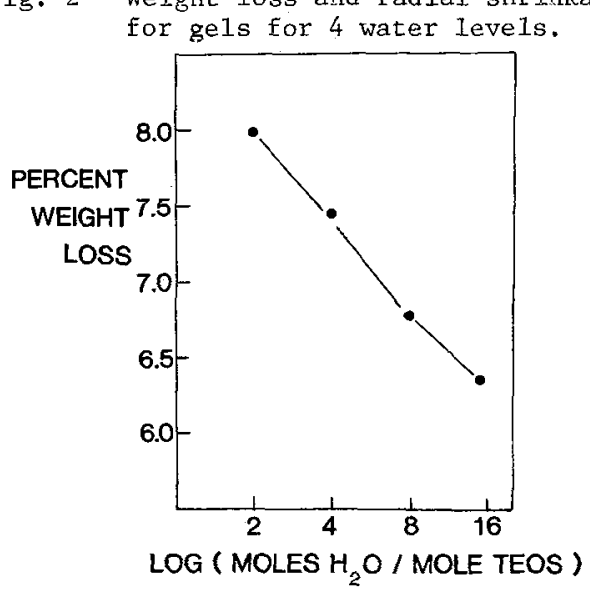

Fig. 4 - Total weight loss according to thermal gravimetry between 120 and $800^{\circ} \mathrm{C}$ for 4 water levels. 
2 moles $\mathrm{H}_{2} \mathrm{O}$ has more weight loss due to water than the gels with higher water levels.

The results of thermal analysis were used to design the 8 hour firing schedule. As indicated in the Table, the monolithic gel prepared with 16 moles $\mathrm{H}_{2} \mathrm{O}$ and dried at $70^{\circ} \mathrm{C}$ (Sample D) has a density of $2.2 \mathrm{~g} / \mathrm{cm}^{3}$ and was a monolithic glass after firing. The final sample size was about $20 \mathrm{~mm}$.

4. Discussion and Conclusions. - As expected, the gels prepared with less water had higher densities, less weight loss on drying and more residual organic than gels prepared with more water. Under acid conditions, a high water level is thought to increase the number of bridging oxygens and eliminate more alkoxy groups $(5,6)$. When all the gels reached a dry condition in equilibrium with atmospheric moisture, they were monolithic and transparent. However, the gel with 16 moles $\mathrm{H}_{2} \mathrm{O}$ showed less total weight loss and less weight loss due to water on firing than the gel with 2 moles $\mathrm{H}_{2} \mathrm{O}$. This behavior can be explained by a polymerization scheme where the high density-10w water gel has low molecular weight polymers with occasional cross-1inks between polymers, while the low density-high water gel has larger polymers which tend to grow individually before cross-linking.

A simple geometrical model was used previously to reconcile BET (5) and SAXS (13) estimates of pore size with weight loss from elimination of hydroxyls on the surface of pores (1). Following this model, the trend towards less weight loss on firing in the low density gels would suggest a progression from cross-1inked chains to cross-linked multiple chains to cross-1inked sheets. Another way of looking at this is a continum from molecular structure to microstructure.

Taking this model one step further, it has been suggested from infrared spectroscopy that a typical spectrum from a gel shows less absorption at $1100 \mathrm{~cm}^{-1}$ than from a melted glass, meaning either rings of large size or chains in the gel (7). This again points to the fact that in a gel the molecular structure becomes its microstructure depending on processing conditions. There is a great deal more work needed to fully characterize the structures of gels, and by comparison with gels, the structure of melted glass.

Acknowledgements. - The authors thank D. Cheppo, D. Gallagher, T. Gallo and H. Melman for technical assistance, the National Science Foundation (DMR 80-12902) for financial support for the work, and the Rutgers Research Council for a trave1 grant.

\section{References}

1. Klein L. C. and Garvey G. J., J. Non-Crystalline Solids 48 (1982) 97.

2. Kamiya K., Sakka S. and Mizutani M., Yogyo-Kyokai-Shi 86 (1978) 553.

3. Yamane M. and Okano S., Yogyo-Kyokai-Shi 87 (1979) 56.

4. Nogami M. and Moriya Y., J. Non-Crystalline Solids 37 (1980) 191.

5. Brinker C. J. and Mukherjee S. P., J. Mat. Sci. 16 (1981) 1980.

6. Brinker C. J. et al., J. Non-Crystalline Solids $\overline{48}$ (1982) 47.

7. Decottignies M., Phalippou J. and Zarzycki J., J. Mat. Sci. 13 (1978) 2605.

8. Tesar A. et al., Bul1. Am. Ceram. Soc. 60 (1981) 364 (Abstract).

9. Dislich H. and Hussmann E., Bull. Am. Ceram. Soc. 59 (1980) 329 (Abstract).

10. Phalippou J., Prassas M. and Zarzycki J., J. Non-Crystalline Solids 48 (1982) 17 .

11. Brinker C. J. and Scherer G. W., Bul1. Am. Ceram. Soc. 61 (1982) 374 (Abstract).

12. Carturan G., Gottardi V. and Graziani M., J. Non-Crystaliine Solids 29 (1978) 41 .

13. Yamane M., Yogyo-Kyokai-Shi 88 (1980) 589.

14. Thomas I. M., U.S. Patent 4, $\overline{02} 8,085$. 